\title{
The effect of phosphocreatine on the distribution of different subunits of translation elongation factor 1 in gently permeabilized human fibroblasts
}

\author{
Boris S. Negrutskii
}

Institute of Molecular Biology and Genefics. National Academy of Sciences of Likraine 150 Zabolotnoge str., Kyiv, 252143 Ckraine,

\begin{abstract}
Highiy eifective permeabilization/translation system developed recently (Negrutskii et al. (1994) Proc. Nat. Acad. Sci. USA 91, 964-968) was used to study the distribution of FITC-labeled $\alpha$ and $\delta$ subunits of transtation elongation factor 1 in human fibroblasts. Somewhat granular fluorescent picture observed for the both proteins distribution during active protein synthesis may be indicative of putative protein synthesis compartments. Exogenous phosphocreatine, an absolutely required agent to support the protein synthesis in permeabilized cells, is shown to influence the EF-la distribution, while not affecting the EF-18. Most of EF-Ia under "low energy" condition is found in nucleus. Thus, the possibility of the functional change in EF-Ja distribution is demonstrated supporting the idea about transient character of EF-IQ involvement into theavy" EF-I complex.
\end{abstract}

Introduction. The protein synthesis is thought to be the most complex and highly organized metabolic process in mammalian cell. Recently a number of evidence have been presented supporting the existence in vivo of structural and functional compartmentalization of the translation machinery. The channcling of aninoacyl-tRNA during protein synthetic process in vivo 11,2] and sequestering of celiular aminoacyl-tRNA [3] are the functional signs of the comparimentalization. The line of structural evidence involves detection of high-molecular aminoacyl-tRNA synthetases $[4,5]$ and elongation factors $[6,7]$ complexes, as well as the cyloskeletal association of translation factors $18 \mathrm{l}$, ribosomes $[9,10]$, mRNA [1] $]$ and aminoacyl-tRNA synthetases $[12,13]$.

The various protein synthesis components have been found recently to be co-localized in granules inside highly specialized glial cclls $[14]$. The detergent-exiracted oligodendrocytes were used to visualize protein (aminoacyl-tRNA synthetase and translation elongation factor $E F-(\alpha)$ and nucleic acid (rRNA and mRNA) components by immunofluorescence and by fluorescent in situ hybridization correspondingly. Such a co-localization has been interpreted as a potential demonstration of the protein

(C) B. S. NEGikUSKH. 1997 synthesis compartments in eukaryotic cell though the functional role of such granules has not yet been verified [14].

In this work we have used somewhat different experimental approach to look at possible functional importance of the structural organization of putative protein synthesis compartments in cell. The fluorescently labeled and functionally active components of the protein synthetic machinery (namely $\alpha$ and $d$ subunits of translation elongation factor EF-1) were used as markers of supposed compartments. The proteins were dcposited into the gently permeabilized human fibroblasts which were able to continue mRNA translation with the high efficiency. The cells were incubated under the conditions supporting or excluding the effective protein synthesis. After fixation the distribution of labeled EF-1 subunits in cell under both conditions was viewed using fluorescent microscopy.

Materials and Methods. Materials. Human EF$1 \alpha$ and $\mathrm{EF}-1 \delta$ were kindly provided by J. Kriek (Lciden University).

Buffers. Buffer A: $40 \mathrm{mM}$ Tris- $\mathrm{HCl}$, pH 7.5, $10 \mathrm{mM} \mathrm{MgCl}, 100 \mathrm{mM} \mathrm{NH}{ }_{4} \mathrm{Cl}, 0.2 \mathrm{mM}$ DTT, $1 \mathrm{mg} / \mathrm{ml}$ bovine serum albumin, $25 \%$ glycerol.

Buffer S: $130 \mathrm{mM}$ sucrose, $50 \mathrm{mM}$ potassium acetate, $50 \mathrm{mM} \mathrm{KCl}, 20 \mathrm{mM}$ HEPES, pH 7.4 . 
Buffer PS: buffer $S$ containing $5 \mathrm{mM}$ ATP, $13 \mathrm{mM}$ creatine phosphate, $5 \mathrm{mM}$ glucose, $6 \mathrm{mM}$ magnesium acetate.

Buffer NPS: buffer $S$ containing $5 \mathrm{mM}$ ATP, $5 \mathrm{mM}$ glucose and $6 \mathrm{mM}$ magnesium acetate.

Buffer FITC: $100 \mathrm{mM}$ carbonate buffer, pH 8. 3, $50 \mathrm{mM}$ sodium chloride, $20 \%$ glyccrol.

Buffer PSW: 20 amino acids mixture $(10 \mathrm{mM}$ of each), $4 \mathrm{mM}$ GTP (neutralized by $\mathrm{KOH}$ ), $1.2 \mathrm{mg} / \mathrm{ml}$ creatine phosphokinase.

Cell culturing. Primary human fibroblasts VH25 from human foreskin (15-18 passages) were grown in Dulbecco's modified Eagle's medium (DMEM) supplemented with $10 \%$ fetal calf serum. After trypsinization they were plated at density of $10-$ $20 \%$ on sterilized glass coverslips in the culture dishes ( 3 coverslips per dish). Cells were allowed to settle overnight and then were either used for experiment immediately or incubated for five more days in DMEM containing $0.5 \%$ fetal calf serum to enter $\mathrm{G}_{0}$ phase of cell cycle.

Preparation of FITC-proteins. Fluorescein isothiocyanate (FITC) was dissolved in DMSO at concentration $1 \mathrm{mg} / \mathrm{ml} . a$ or $\delta$ subunits of EF-1 were dialyzed against FITC buffer ffinal concentration $2 \mathrm{mg} / \mathrm{ml}$ ). $14 \mu$. of dye were mixed with $140 \mu l$ of protein solution and were incubated two hours at room temperature. Then $2 \mathrm{M} \mathrm{NH} \mathrm{NH}_{4} \mathrm{Cl}$ (final concentration $50 \mathrm{~mm}$ ) was added to quench the reaction and the proteins were separated from free dye by microcolumn Sephadex G-25 chromatography. To test the absence of free FITC in FiTC-EF-1 preparations the portions of G-25-purified FITC-EF-1a and FITCEF-10 were subjected to SDS-PAGE. No fluorescence was found in low-molecular region.

Cell permeabilization. All procedures were conducted at $37{ }^{\circ} \mathrm{C}$. Cells grown on coverslips were washed two times with $2 \mathrm{ml}$ phosphate-buffered saline and once with $2 \mathrm{ml} \mathrm{S}$ buffer per dish. $1 \mathrm{ml}$ of saponin in buffer $\mathrm{S}$ (final concentration $125 \mu \mathrm{g} / \mathrm{ml}$ ) was added to cach dish and cells were incubated 6 min. Then saponin was aspirated and cells were carefully washed twice with $2 \mathrm{ml}$ PS or NPS buffer depending on further incubation. PS buffer was designed to effectively support the protein synthesis in permeabilized cells [2], while NPS buffer was the same buffer without creatine phosphate. The latter is shown to be the absolutely required component of the protcin synthesis mixture and its withholding leads to the complete stop of the mRNA translation [2].

FITC-protein labeling of the cells. $10 \mathrm{ml}$ of FITC-protein $(\approx 0.5 \mathrm{mg} / \mathrm{ml})$ were mixed with $1.2 \mu 1$ of PSW buffer, $12 \mu 1$ of ovalbumin in PS or NPS buffer (final conceniration $2 \mathrm{mg} / \mathrm{ml}$ ) and $27.6 \mu 1$ of PS or NPS buffer. $40 \mu l$ of mixture were gently applicd on the coverslip with permeabilized cells. The incubation was continued at $37^{\circ} \mathrm{C}$ for $7 \mathrm{~min}$ unless indicated otherwise. The coverslips were washed with PBS and $0.5 \mathrm{ml}$ of $3.8 \%$ formaldehyde was carefully applied per coverslip. Cells were left for $15 \mathrm{~min}$ a1 room temperature. Fixed cell were washed thoroughly with PBS, and excess of liquid was carefully aspirated by filter paper. $5 \mu 12.3 \%$ DABCO $(1,4$-di-azabicyclo- $(2,2,2)$-octane) anti-bleaching agent were added per coverslip. The coverslips were mounted at object glasses with nail polish. Slides were observed with a microscope equipped for fluorescence microscopy. The level of accumulation of FITC-EF-l $\alpha$ in the nucleus was quantitated as described earlier $[15]$.

$l^{3} H J G D P$ binding test. Increased amounts of EF-1 $\alpha$ or FITC-EF-l $\alpha$ were incubated in the buffer A containing $4 \mu \mathrm{M}\left[\mathrm{H}^{3}\right] \mathrm{GDP}$ (total volume $20 \mu \mathrm{l}$ ) for 5 min at $37^{\circ} \mathrm{C}$. Then samples were put on ice, diluted with $100 \mu 1$ of the ice-cold same buffer without BSA. EF-1 $a \cdot\left[H^{3}\right] G D P$ complexes were absorbed on nitrocellulose filters (pore diameter $0.4 \mu \mathrm{m}$ ) and washed twice with $200 \mu$ l of the sanc buffer without glycerol.

Protein synthesis in permeabilized cells. To test cell protcin-synthetic activity in situ the permeabilized $\mathrm{G}_{0}$-fibroblasts grown on the coverslips were incubated in miniature Petri dishes (one coverslip per dish) in $75 \mu 1$ PS buffer containing $0.4 \mathrm{mM}$ GTP, $30 \mu \mathrm{g} / \mathrm{ml}$ creatine phosphokinase, $\left.240 \mu \mathrm{M} \mathrm{I}\right|^{35} \mathrm{~S}$ Imethionine and the 19 amino acids mixture (methionine omitted), 240 $\mu \mathrm{M}$ of each, at $37^{\circ} \mathrm{C}$. At the end of incubation $1 \mathrm{ml}$ $10 \%$ hol TCA was added to each dish to stop the reaction. Then TCA-insoluble suspension was evacuated into glass tubes, boiled $15 \mathrm{~min}$ and absorbed on Whatman GF/C filters. The coverslips were transferred to plastic scintillation vials and boiled for $15 \mathrm{~min}$ in $0.2 \mathrm{ml}$ of $10 \%$ TCA. Samples were treated according to the procedure for filter or liquid/liquid radioactivity counting correspondingly. Data for each time point, corrected for zero point radioactivity, represent the summation of the corresponding coverslip and filter radioactivities.

Results. Adjustments of the permeabilization-protein synthesis system. Three main prerequisites to study the functional distribution of fluorescently labeled EF-I in permeabilized cells are: i) the development of very gentle procedure to permeabilize the cell membrane without perturbing the internal structure of cell ii) high protein synthetic activity of the permeabilized cell iii) low-ievel labeling of EF-1 subunits with fluorescent agent. All threc preconditions were shown to be fulfilled in this study.

First, since the gentle pcrmeabilization method has been developed for CHO cells in suspension 121 it was necessary to find the conditions rendering the human fibroblasts completely permeable in situ. Wide range of the saponin concentration $(30-500 \mu \mathrm{g} / \mathrm{ml})$ was tested. $125 \mu \mathrm{g} / \mathrm{ml}$ concentration of the detergent 
is determined to make $100 \%$ cells accessible to trypan blue without visible destruction of cell menbranes.

Sccond prerequisite to study the functional EF-1 localization in cell was to prove the high protein synthetic activity of the permeabilized fibroblasts. Lincar incorporation of $\left[{ }^{35} \mathrm{~S}\right]$ methionine into hot TCA-insoluble product for at least $15 \mathrm{~min}$ was demonstrated (Fig. 1). Thus, the EF-1 localization study (incubation time $8 \mathrm{~min}$ ) was performed during active protein synthesis in cell.

Third, the conditions of FITC-labeling of the EF-1 subunits were adapted to preserve the factor activity in the protein synthesis. Namely, $\mathrm{pH}$ of the labeling buffer was decreased to 8.2 and incubation time at room temperature was reduced to 2.5 hours to modify the conventional procedure $[15,16]$. Since $\mathrm{EF}-1 \alpha$ is the most labile protein in the EF-1 complex and contains much greater amount of lysines per molecule in comparison with other subunits of EF-1 the effect of FITC labeling on the EF-1 $\alpha$ activity was tested. No marked difference was found in the activity of FITC-EF-1 $a$ and non-labeled $\mathrm{EF}-1 e^{*}$ in $\left.{ }^{3} \mathrm{H}\right] \mathrm{GDP}$ binding (data not shown).

$E F-1 Q$ and $E F-I \delta$ localization in human fibroblasts. Since the ATP-regentrating system was shown

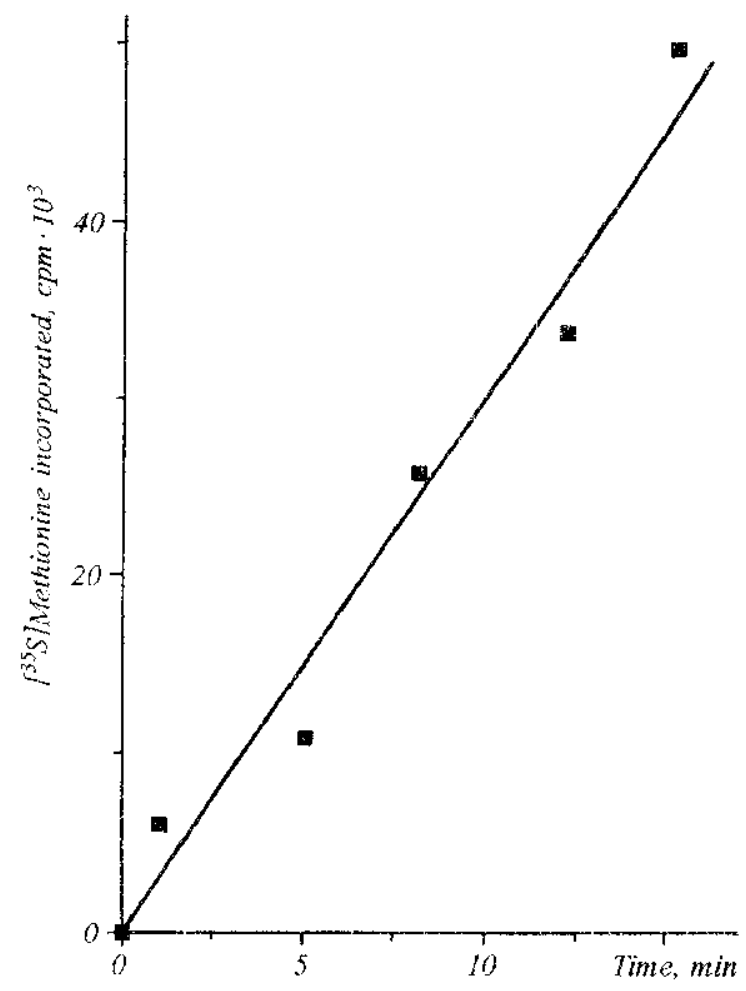

Fig. 1. Kinetics of $\mathrm{r}^{35} \mathrm{Simethionine} \mathrm{incorporation} \mathrm{into} \mathrm{hot} \mathrm{TCA-}$ insoluble product is permeabilized human fibroblasts to be an absolute requirement for the protein synthesis in permeabilized cells [2] it was of interest to find out whether distribution of different subunits of EF-1 in permeabilized cells depends on the energy supply. Fig. 2 demonstrates the FITC-EF-1 $a$ distr1bution in saponin-permeabilized $\mathrm{G}_{0}$-human fibroblasts in the presence of creatine phosphate $(A)$ or without it $(B)$. The major portion of EF-1 $a$ is observed in the nucleus in the absence of creatine phosphate (Fig. 2, $B$ ). Fig. 3 demonstrates time-course of the FITC-EF$1 \alpha$ entry into the nucleus of permeabilized cell. Much less amount of the factor is detected in the nucleus if ATP-regenerating system functions actively (Fig. 2, A). Contrary to EF-lo, the EF-1 $\delta$ localization in permeabilized $G_{0}$ human fibroblasts was not influenced by the presence of creatine phosphate in the incubation mixture (Fig. $4, A$ and $B$ ). Somewhat granular distribution throughout the cytoplasm is found for both proteins being is more evident in the case of EF-1ס.

The controls. To decrease the unspecific absorption of the FITC-labeled EF-1 subunits inside permeabilized cells nearly 5 -fold excess of ovalbumin over EF-1 was included in the permeabilization medium. Ovalbumin has similar to EF-1a molecular weight $(43 \mathrm{kDa}$ ) allowing to penetrate the nucleic membrane. FITC-labeled ovalbumin is found dispersed evenly throughout the permeabilized fibroblasts ([16], our unpublished observation). It should bc noted that addition up to $6 \mathrm{mg} / \mathrm{ml}$ ovalbumin and albumin into the incubation mixture had virtually no effect ai the overall picture of FIrC-EF-1 subunits distribution (data not shown). To test the functional importance of the EF-1 localization observed the inactivated FITC-labeled protein was used as a control. The incubation of EF-1 $\alpha$ without glycerol is known to cause fast and unrecoverable loss of GDPbinding activity of the factor 1181. Therefore, FITCEF-1 $\alpha$ was inactivated by 6 hours incubation in glycerol-free buffer (40 mM HEPES, $\mathrm{pH} 7.5$ ) at room temperature. The inactivation of $E F-1 \alpha$ caused the less retention of the protein in cell (Fig. $2, C$ ). The distribution of inactive FITC-EF-1a in cell incubated with the complete energetic mixture was shown to be strictly nuclear (Fig. 2, C), resembling to some extent that of active FITC-EF-1 $\alpha$ under the slow energy" conditions (Fig. 2, B). So, certain specificity of the energy-dependent re-distribution of FITC-EF- $1 \alpha$ in human fibroblasts may be suggested.

Discussion. The study of the intracellular localization of a protein may be escorted by the variety of artifacts. The severe methods of cell permeabilization used in conventional procedures may lead to the re-distribution of proteins into uncharacteristic cellular compartments [16]. Therefore, one should take care to avoid as much as possible the destruction of 

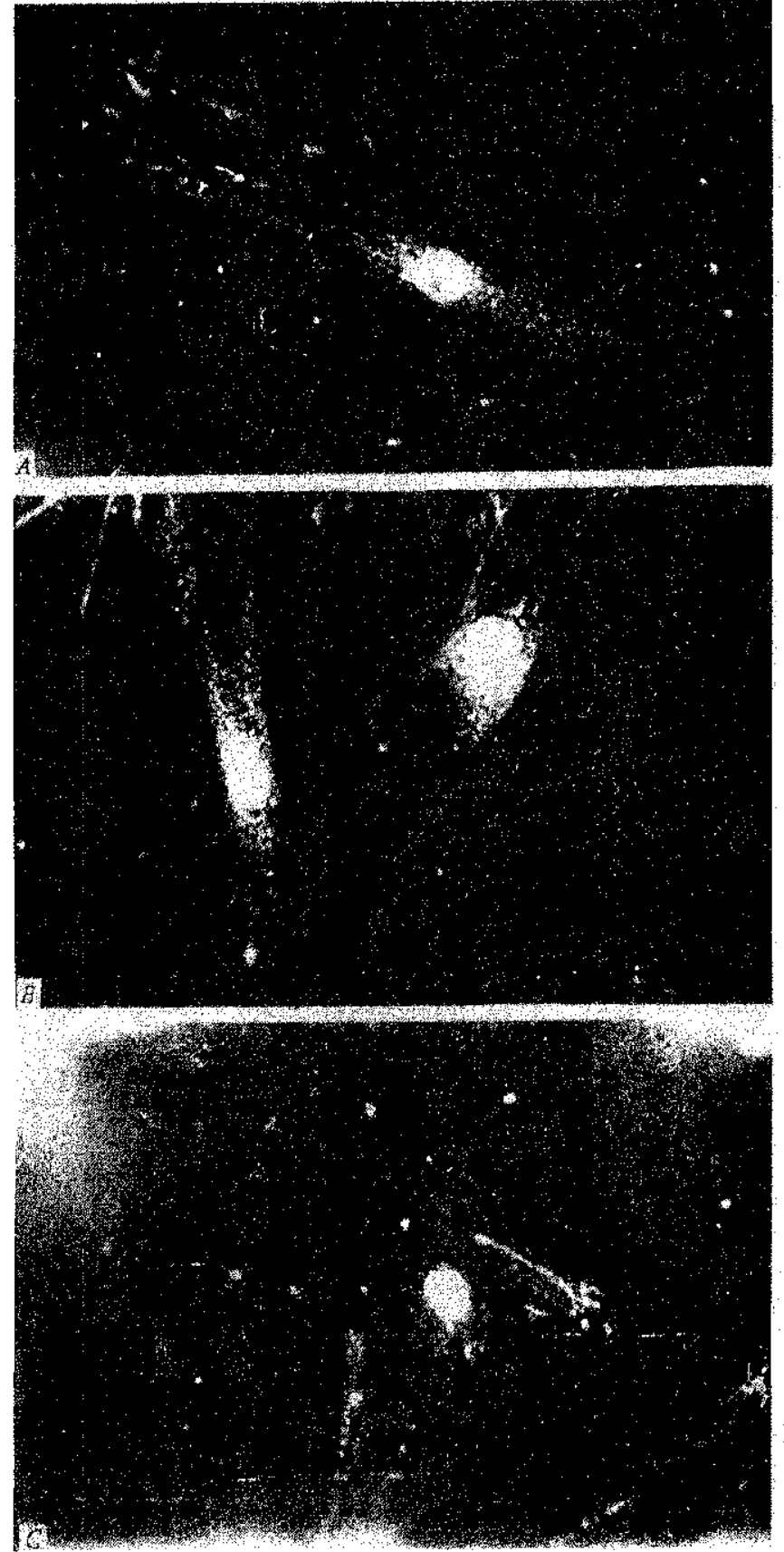

Fig. 2. The distribution of FITC-EF $: 1 \alpha$ in permeabilized human fibroblasts: $A-$ cells were incubated in complete protein synthesis mixture; $B$... in the same but phosphocreatine mixture; $C$ - distribution of inactivated FITC-EF-I $\alpha$ in cells studied in complete protein synthesis mixture

the internal structure of cell during study of the protein localization. The gentle permeabilization system developed by us recently for studying the aminoacyl-tRNA channeling for protein synthesis in euka-

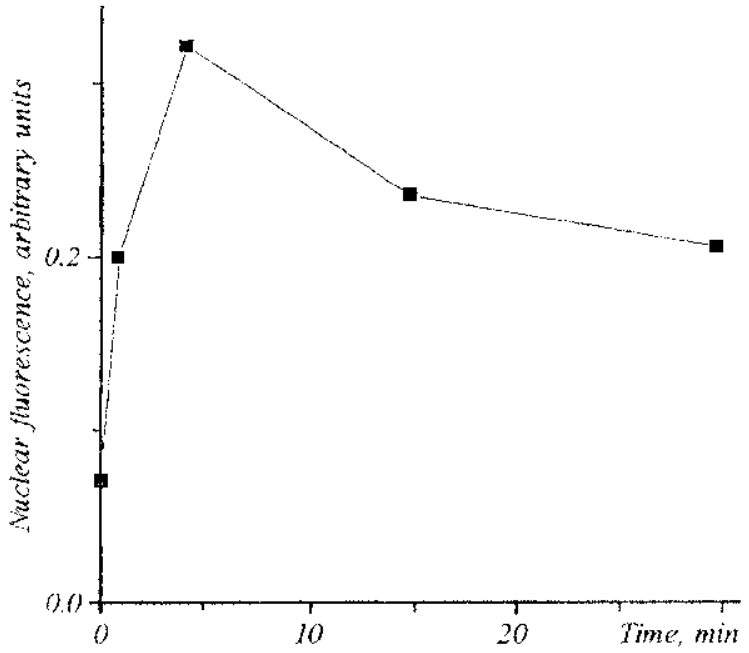

Fig. 3. Time-course of FIIC-EF-l $\alpha$ cntry into the nuclei of permeabilized human fibroblasts incubated in complete protein synthesis mixture withou phosphocreatine. Cells were treated as described in Materials and Methods, fixed at limes indicated, washed and photographed. The intensivity of fluorescence at different time-points was calculated by scaming densitometry of the nuclet. No noticeable changes in the intensivity of cytoplasmic fluorescence was found in the interval between one to thirty minutes

ryotic cells [2] suits well to this purpose. On the other hand, the permeabilized cell system in which the protein synthesis persists with the activity indistinguishable from that of intact cells [2] gives a good opportunity to study the location of the protein synthesis apparatus in situ in the conditions matching its native surrounding in cell.

The $G_{0}$-arrested human fibroblasts were used for the experiments. The protein synthesis in the quiescent cells is slowed down significantly while the pattern of proteins synthesized are quite similar to that in the growing cells $[17]$. Thus, $G_{0}$ cells may be taken as a reference point to portray low functional level of the translation machinery. The protein synthetic process was shown to proceed linearly in permeabilized $G_{0}$ cells for at least $15 \mathrm{~min}$ after supplementing with the necessary components (Fig. 1).

Somewhat granular EF-1 localization is observed in permeabilized cells which continue to synthesize proteins (Fig. 2, $A, 4, A$ ). Most of fluorescence is found throughout the cytoplasm. It is noteworthy that granular appearance of EF-1 $\delta$ in human fibroblasts has been demonstrated also by immunofluorescent technique $[19]$. These data appear in agreement with 


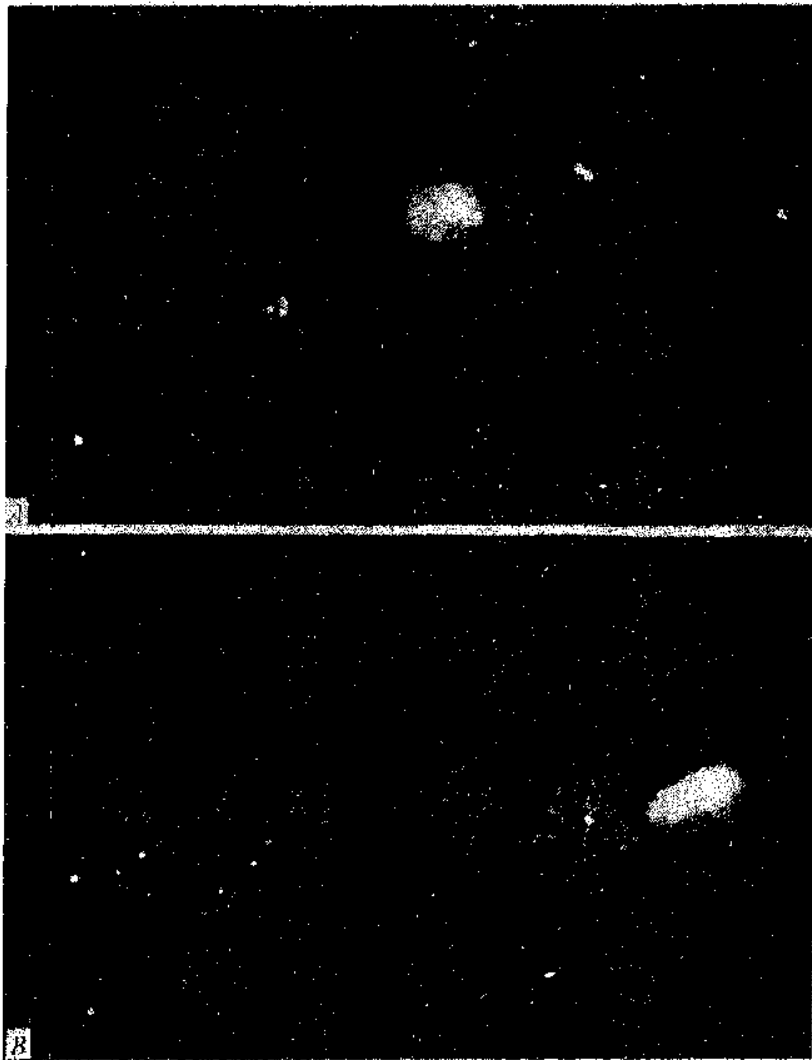

g. 4. The distribution of FITC-EF-1 $\delta$ in permeabilized fibroblasts complete protein synthesis mixture $(A)$ or in the same mixture thout phosphocreatine $(B)$

cent finding of the large granules containing RNA, rRNA, EF-lo and arginyl-tRNA synthetase ! oligodendrocytes $\{14 \mid$. It was suggested that these ains represent actual protein synthesis compartents 114$]$. Here we showed that the involventent of te essential component of protein synthesis machiery, EF- $x$, in supposed protein synthesis compartents may depend on the efficiency of translation ocess in cells (Fig. 2, $A, B$ ). To our knowledge, this the first demonstration of the energy-dependent :-distribution of the translation elongation factors in akaryotic cell. Earlier, it was found that inactivation

EF-2 itself by diphtheria toxin or inhibition of sllular protein synthesis by ribosome inhibitor, ricin, id not change the distribution of EF-2 in human broblasts 181 .

Cortain correlation could be found between the istribution of EF-2 in $G_{0}$ and cycling cells measured $y$ immunofluorescence $[2]$ and the distribution of $F-1 \alpha$ in permeabilized $G_{0}$ cells under low and high :vel of protein synthesis conditions (Fig. 2) corresondingly. It cannot be excluded that such a reistribution of protein synthesis components may reflect some rearrangement of protein synthesis compartments under low functional level of the translation machinery.

Some non-specific fluorescent staining of the nucleus was observed for any FITC-labeled protein studied which molecular size fitted to the size of the nuclear membrane pore (data not shown). FITC-EF10 (29 kDa) and FITC-ovalbumin (43 kDa) location in permeabilized cell demonstrate no creatine phosphate dependence while the presence of ATP-regenerating mixture which is of crucial importance for protein synthesis in permeabilized cells $\{2\}$ caused the noticeable exclusion of EF-1a from the nucleus (Fig. 2, A, B). This fact may be connected also with the functioning of ATP-dependent system of nuclear transport $[5]$.

However, this system is known to implicate mainly large proteins which cannot pass through the nuclear membrane passively $[15]$. The time-dependent and reversible character of the FITC-EF-10 presence in the nucleus of permeabilized cell (Fig. 3) suggests that the accumulation of $\mathrm{EF}-1 \alpha$ does not involve strong intranuclear binding. The nuclear localization of EF-ict has been demonstrated independently by immunofluorescence and immunoelectron microscopy $[14,19]$ and was considered to represent other than translational functions of EF-I $\alpha$. On the other side, it cannot be excluded that EF-le plays a role in transfer of newly synthesized tRNA from nucleoli to translational compartments. Discovered recently ability of EF-1 $\alpha \cdot G D P$ to interact with uncharged tRNA [21] makes such a suggestion even more likely.

The difference observed in the phosphocreatine dependence of EF-1 $x x$ and EF-1 localization seems to be consistent with the commonly accepted view on the EF-1 complex $[22]$. According to the model, EF-1 $\delta$ is the part of EF-1 $\beta \gamma \delta$ complex associated with cellular structures while EF-1 $\alpha$ interacts with the complex transiently during active protein synthesis. Consistently, similar distribution of $\alpha$ and $\delta$ subunits of EF-1 was observed under active protein synthesis condition while significant re-arrangement of EF-I $\alpha$ localization was found under the translational arrest (Fig. 2). EF-1 $\delta$ localization appeared alike under the both conditions (Fig. 4).

To substantiate the protein synthesis effect on EF-1 localization we attempted to modulate the translation restriction by other than the energy depletion means, namely, by addition of protein synthesis inhibitor, cycloheximide, to the perforated cells. Unfortunately, the addition of cycloheximide to permeabilization mixture was shown to be accompanied by noticeable destruction of perforated cells (data not shown) which impeded correct protein localization measurements. 
The attempt to get a definite answers whether phosphocreatine effects EF-la disiribution through inhibition of protein synthesis and what is the main reason of EF-lo nuclear localization will be a subject of further investigation.

I wish to thank Prof. Wim Möller and Dr. Jan Dijk for invaluable help in performing the investigation. I am indebted to Dr. Romas Stapulionis for sharing recent achievements in permeabilization technique. The support of short-term FEBS fellowship program is appreciated. Partial support of the Ministry of Science and Technology of Ukraine (grant $5.2 / 130$ and 5.4/73) is acknowledged.

\section{Б. C. Легруцькиі}

Вилив фосфокреатину на локалізацію різних субоциницц фактора елонгації транслялії 1 в м'яко пермсабылізованих фібробластах нющини

Резіоме

Фосфокреатин г: абсолюпно необхідния компонентом суміші для білкового синтезу у безкиітинни системах mа пермеабілізованих клітинах. ПЈоказано, що під впливом фосфокреапину зміновпеся локалізація а-субодиниці фактора елонації mрансляиї I у пермеабілізованих кліминах виних еукаріот.

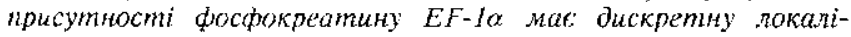
зацію в цитоплазмі, а за його вidcymticmo бinbiaicn $E F-I \alpha$ лосалізовано у ядрі. Pозподіл $\delta$-субодиниці EF-l не залежить

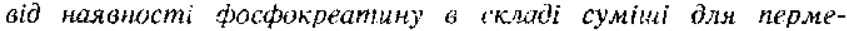
aбinizaüit.

\section{b. C. Hezpущкиі}

Bлияние фосфокреатина на распределение различных субъсдиниц фахтора элонгации трансляции 1 в пермеабилизованных фибробластах человека

резюме

Фосфокреатин абсолюнио необхобини для обесненени белковосо синтеза в бескліпочных системах и в пермеабилизованных клетках. ПІоказано, что локализация EF-Iо в пермеабилизованиых кнетках зысиих эукариот зависит он присутствия фосфокреапина в среdе. Pacnpedene'tue EF-Ja \& uитоплазме в nрисутствии фосфокреатина носит дискретньй характер, тогда как этот белок обиаруживается преимуцестиенио $в$

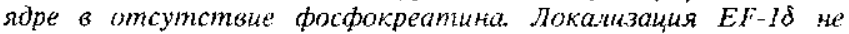
зависит от натиния фосфокреатина в смеси б.ля пер.иеабилизации.

\section{REFERENCE}

1. Negrutskii B. S., Deutscher $M$. $p$. Channeling of aminoacyl1RNA for protcin synthesis in vivo // Proc. Nat. Acad. Sci. USA. - 1991 - -88.-P. $4991-4995$.

2. Negrutskii B. S., Stapulionis R., Deutscher M. P. Supramolecular organization of the mammalian translation system // [bid.-1994.-91.-P. 964-968.

3. Negrutskii B. S., Deutscher M. P. A sequestered pool of aminoacyl-1RNA in mammalian cells // Ibid -1992 -89.-P. $3601-3604$.

4. Deutscher M. P. The eukaryotic aminoacyl-tRNA synthetase complex: suggestions for its structure and funcrion $/ / \mathrm{J}$. Cell Biol.-1984.-99.-D. 373-377.

5. Mirande $M$ Aminoacyl-tRNA synthctase family from pro- karyotes and eukaryotes: Siructural domains and their inplications // Progr. Nucl. Acid Res. Mol. Biol-1991.-40.P. $95-142$.

6. Bollini R., Soffiontini A. N., Bertani A., Lanzani G. A. Some molecular properties of the clongation factor $E F-1$ from wheat embryos // Biochemistry.-1974.-13.-P. $5421-5425$.

7. Crechet J. B., Canceill D., Bocchini V., Parmeggiani A. Characterization of the elongation factors from calf brain $1 / /$ Eur. J. Biochem.-1986.-161.-P. 635-645.

8. Shestakova E. A., Motuz L. P., Minin A. A., Gavrilova L. P. Study of localization of the protein-synthesizing machinery along actin filament bundles // Cell Biol. Int.--1993.-17.P. $409-416$.

9. Hesketh J. P., Pryme $I, F$. lnteraction between mRNA, ribosomes and the cytoskeleton // Biochem. J.-1991.-277.P. $1-10$.

10. Hesketh J. E., Horne Z., Campbell G. P. Immunohistochemical evidence for an association of ribosomes with microfilaments in 3 T3 fibroblasts i/ Celi Biol. Int. Rep. -1991.-15.-P. 141150 .

11. Bassel $G$, Powers $C$., Taneja $K$., Singer $R$. Single mRNAs visualized by ultrastructural in situ hybridization are principatly localized at actin filament intersections in fibroblasts // $\mathbf{J}$. Cell Biol.-1994.-126.-P. 863-876.

12. Dang C.V., Yang D. C. H., Pollard T. D. Association of methionyl-tRNA synthetase with derergent-insoluble components of the rough endoplasmic reticulum //Ibid.--1983.-96. - P. 1138-1147.

13. Mirande $M$., le Corre D., Louvard D. et al. Association of an aminoacyl-tRNA synthetase complex and of phenylalanyl-tRNA synthetase with the cylosketelal framework fraction from mammalian celis // Exp. Cell Res.-.-1985.-156.-P. 91-102.

14. Barbarese E., Koppel D. E., Deutscher $M$. P. et al. P'rotein translation components are colocalized in granutes in oligodendrocytes // J. Cell Sci.-1995.-108.-D. $2781-2790$.

15. Newmeyer D. D., Finlay L. R., Forbes D. J. In vitro transport of a fluorescent muclear protein and exclusion of non-nuclear proteins // J. Cell Biol.-1986.-103.--3. 2091-2102.

16. Melan $M$. A., Sluder $G$. Redistribution and differential extraction of soluble proteins in perneabilized cuitured cells // J. Celi Sci.-1992.-101.-P. $731-743$.

17. Pardec A. B. $G_{1}$ events and regulation of cell proifferation // Science.-1989.-246.-.P. 603 - 608

18. Carvalho M. G., Corvalho J. F., Merrick W. C. Biological characterization of various forms of elongation factor 1 from rabbit reticulocytes// $\Lambda$ rch. Biochem. and Biophys. -1984.234.-.P. 603-611.

19. Sanders J., Brandsma M., Janssen G. M. C. et al. Immunofluorescence studies of human fibroblasts demonstrate the presence of the complex of elongation factor- $1 \beta \delta$ in the endoplasmic reticulum $/ / \mathrm{J}$. Ceif Sci.-1996.-109.P. $1113-1117$.

20. Shestakova E. A., Motuz L. P., Gavrilova L. P. Co-incalization of components of the protein-synthesizing machinery with the cytoskeleton in $G_{0}$ arrested cells $/ /$ Cell Bicl. Int. Rcp.-.1993.-17.--P. 417-424.

21. Petrushenko Z. M., Negrutskii B. S., Ladokhin A. V. et al. Evidence for the formation of an unusual ternary complex of rabbit liver EF $-1 \alpha$ with GDP and deacylated tRNA // FEBS Lett. $-1997 .-407 .-\mathrm{P} .13-17$.

22. Janssen G. M. C., van Damme H. T. F., Krick J. et al. The subunit structure of elongation factor 1 from Artemia. Why two $\alpha x$-chains in this complex? // J. Biol. Chem.-1994.-269.P. $31410-31417$.

Received 28.02 .97 